\title{
Cracow Circle and Its Philosophy of Logic and Mathematics
}

\author{
Roman Murawski
}

Received: 22 July 2014 / Accepted: 20 October 2014/Published online: 30 October 2014

(C) The Author(s) 2014. This article is published with open access at Springerlink.com

\begin{abstract}
The paper is devoted to the presentation and analysis of the philosophical views concerning logic and mathematics of the leading members of Cracow Circle, i.e., of Jan Salamucha, Jan Franciszek Drewnowski and Józef (Innocenty) Maria Bocheński. Their views on the problem of possible applicability of logical tools in metaphysical and theological researches is also discussed.
\end{abstract}

\section{Keywords Cracow Circle $\cdot$ Philosophy $\cdot$ Mathematics $\cdot$ Logic $\cdot$ Theology}

The term 'Cracow Circle' is used to describe a group of people who tried to apply the methods of modern formal/mathematical logic to philosophical and theological problems, in particular they attempted to modernise the contemporary Thomism (the trend which was then prevailing) by the logical tools. The group consisted of: the Dominican Father Józef (Innocenty) M. Bocheński, ${ }^{1}$ Rev. Jan Salamucha, ${ }^{2}$ Jan

\footnotetext{
1 Józef (Innocenty) Maria Bocheński was born in Czuszów (District of Miechów) on 30 August 1902. He began the studies of law in Lvov in 1920. Then he moved to Poznań (in 1922) where he studied economy. However, he did not finish his studies. In 1926, he entered the major theological seminary in Poznań, and in 1927, he joined the Dominicans. In the years 1928-1931, he studied philosophy in Fribourg (Switzerland), where he received his doctor's degree. In the years 1931-1934, he studied theology at the Angelicum in Rome-he also obtained his doctorate there. From 1934, he lectured on logic at the Angelicum. In 1938, he presented his Habilitationsschrift to the Theological Faculty of the Jagiellonian University in Cracow. During World War II he served as chaplain to the Polish Army and the Polish II Corps in Italy. In the years 1945-1972, he was a professor at the University of Fribourg. In 1948, he received the Chair of the History of Modern Philosophy there. In 1958, he founded the Institute of Eastern Europe at the University of Fribourg. He died in Fribourg on 8 February 1995.

2 Jan Salamucha was born in Warsaw on 10 June 1903. In 1919, he entered the major seminary in Warsaw, and in 1925 he received the Sacrament of Holy Orders. In 1920, he was a medical orderly in the
}

R. Murawski $(\bowtie)$

Faculty of Mathematics and Computer Science, Adam Mickiewicz University, ul. Umultowska 87,

61-614 Poznan, Poland

e-mail: rmur@amu.edu.pl 
Franciszek Drewnowski ${ }^{3}$ and the logician Bolesław Sobociński who collaborated with them. 26 August 1936 is regarded as the foundation date of the Cracow Circle. ${ }^{4}$ On that day a special meeting was held during the Third Philosophical Congress in Cracow. The meeting gathered 32 people, including professors of philosophy of the theological academies and major theological seminaries as well as the future members of the Circle. It was presided over by the outstanding philosopher and specialist in Medieval studies Rev. Konstanty Michalski. Another participant was Jan Łukasiewicz, one of the key representatives of the Lvov-Warsaw School ${ }^{5}$ specifically of the Warsaw School of Logic-who himself had dealt with philosophy and formulated a programme of a radical reform of this domain, suggesting the use of the methods of modern logic. Łukasiewicz formulated this programme in the paper 'O metodę w filozofii' [On Method in Philosophy] (1927).

During the meeting Łukasiewicz, Bocheński, Salamucha and Drewnowski presented their views and then a discussion was held. The proceedings were published in 1937 in volume 15 of Studia Gnesnensia under the title Myśl katolicka wobec logiki wspótczesnej [Catholic Thought in Relation to Modern Logic].

In fact, the contacts and collaboration between those who were members of the Cracow Circle began earlier—cf. Bocheński (1989)—and the above mentioned meeting was rather a public manifestation. According to Bocheński the Circle existed for seven years-from the beginning of his friendship with Salamucha till the outbreak of World War II.

Footnote 2 continued

Polish-Soviet war. In the years 1923-1927, he studied philosophy, mathematics and mathematical logic at the University of Warsaw where he listened to the lectures by Jan Łukasiewicz, Stanisław Leśniewski, Tadeusz Kotarbiński, Władysław Tatarkiewicz and Stefan Mazurkiewicz. He obtained his doctor's degree in 1927. From 1927 till 1929, he studied at the Pontifical Gregorian University in Rome. Till 1933, he lectured on philosophy at the major seminary in Warsaw. In 1933, he completed his habilitation but it was recognised by the ministry only in 1936. In the year 1934, he also began lecturing at the Jagiellonian University. In November 1939, he was arrested, together with other professors of the Jagiellonian University, and transported to the concentration camp in Sachsenhausen and from there to Dachau. He was released in January 1941 and forced his way to Warsaw where he was active in the underground movement. During the Warsaw Uprising he was a chaplain. He was killed on 11 August 1944.

3 Jan Franciszek Drewnowski was born in Moscow on 2 December 1896. He lived in Warsaw from 1903. In 1914, he attended technical courses in Warsaw and in 1915 he studied at the Mathematical-Physical Faculty in Petersburg. In 1916, he completed a course of engineering at the Military School in Petersburg and served as officer in the Russian army. In 1918, he was drafted into the Polish army and in 1920 he was an officer of the general headquarters. At the same time, he attended lectures at the Faculty of Finance and Economics of the School of Political Sciences. In 1921-1927, he studied philosophy, mathematical logic and mathematics at the University of Warsaw under the supervision of Stanisław Leśniewski, Jan Łukasiewicz and Tadeusz Kotarbiński. In 1927, he obtained his doctor's degree under Kotarbiński's supervision. His dissertation concerned Bolzano's theses on logic. During the defence of Warsaw in 1939 he was an aide-de-camp of the commander of sappers. After the capitulation he was in a German prisoner-of-war camp until 1945. Then he was in the Polish Forces in Rome and England. He returned to Poland in 1947. He was an advisor to the minister in the Central Planning Office and a scientific consultant in the Institute of Economics and Organisation of Industry. He was also an editor of technical dictionaries. He died in Warsaw on 6 July 1978.

${ }^{4}$ Here we cannot give more details about the history of the Cracow Circle-more information on this theme can be found, for example in Wolak (1993, 1996), cf. Bocheński (1989) as well as Woleński (2003).

5 On the Lvov-Warsaw Philosophical School see Woleński (1989). 
The four people who composed the nucleus of the Circle shared interests in mathematical logic as well as philosophical and theological issues. Bocheński was a doctor of philosophy and theology; he was a professor at the Angelicum in Rome. Salamucha studied philosophy, mathematics and mathematical logic at the University of Warsaw, received his $\mathrm{PhD}$ in philosophy at the Jagiellonian University, studied at the Gregorian University in Rome, and when the Circle was created he was a professor of philosophy at the Warsaw Major Seminary. Drewnowski, who was T. Kotarbiński's disciple, was the editor and publisher of Rocznik Handlu i Przemystu [Yearly Reports on Trade and Industry] in Warsaw. Sobociński, a philosopher and logician, was an assistant at the University of Warsaw, and he dealt mainly with formal logic. As opposed to the first three men he did not publish any works on philosophy but he participated in all of the meetings of the Circle and in a way was an expert on logical problems.

The members of the Cracow Circle were fascinated with modern formal logic but were dissatisfied with the level and way of cultivating philosophical and theological reflections of their times. Consequently, they proposed a complete axiomatisation and formalization of the Catholic doctrine, especially Thomism. It should be added that they all respected Thomism. Salamucha and Bocheński regarded themselves as Thomists. Nevertheless, they wanted to change it and transform it into a normal scientific theory. They thought that Catholic thinkers were not faithful to their sources, i.e. scholasticism. Rejecting modern logic they did not follow the spirit of St Thomas Aquinas who had made use of then existing logical apparatus in his philosophical and theological analyses. The Circle postulated a reform of philosophy, first of all its methods and not its content. They did not intend to give up traditionalistic philosophy but wanted to make it precise and develop it in a scientific way. Moreover, the representatives of the Circle thought that the new research methods, using the instruments of modern logic, allowed them to discover numerous valuable elements in the old philosophical and theological texts. They were highly critical about the philosophical systems that had originated between the sixteenth and the nineteenth centuries, including Neo-Scholasticism. Their criticism focused on the methodology of those systems. In particular, they criticised Hegel's philosophy 'not because it was idealistic, but because it was confused, badly stated and insufficiently justified' (Bocheński 1989, p. 12). Additionally, the Circle rejected Neopositivism and all minimalistic philosophies.

As mentioned before, the members of the Cracow Circle were predominantly concerned with methodological problems. They aimed at reforming the traditional way of thinking and writing, which characterised Catholic philosophers and theologians. In addition, they were convinced that modern mathematical logic could be used in philosophical and theological investigations. As Bocheński writes, they postulated that

(1) the language of philosophers and theologians should exhibit the same standard of clarity and precision as the language of science; (2) in their scholarly practice they should replace scholastic concepts by new notions now in use by logicians, semioticians, and methodologists; (3) they should not shun occasional use of symbolic language. To put it briefly the Circle wanted to 
persuade catholic thinkers and writers to adopt the "style" of philosophizing cultivated by the Polish logical school (1989, pp. 11-12).

Łukasiewicz's influence on the Circle and its programme was obvious. Bocheński writes:

This is not surprising as all the members of the Circle, with the exception of myself, had been his pupils. His were the methodological postulates, the criticism of modern philosophy, and the doctrine of the neutrality of logic, stated explicitly for the first time at a meeting of the Circle in 1934. And again, the inquiries by some members of the Circle into the ancient and medieval logic were in fact the continuation of the pioneering work done by Łukasiewicz (1989, p. 12).

It should be added that the Circle had to face aversion and misunderstanding shown by the followers of the official theology. Its method, using mathematical logic, aroused resistance and opposition. The philosophical interpretations formulated by means of this method were accused of anti-metaphysicism, atheism, conventionalism, relativism, pragmatism, positivism and other opposing views to Christian doctrine. The use of logical methods was connected-completely unjustifiably - with the attitude towards religion of such logicians as B. Russell, T. Kotarbiński or the whole Vienna Circle. Refuting these accusations, the representatives of the Cracow Circle firmly defended the neutrality of mathematical logic with respect to philosophy. Thus they shared the views of the Lvov-Warsaw School, opposing the Vienna Circle.

The originality and significance of the conceptions formulated by the Cracow Circle should be stressed. Later similar attempts were made by individual scientists, for example Bendiek (1949, 1956) or Clark (1952). However, they worked on their own account and did not form any group; consequently, their achievements are not as remarkable as those of the Circle. Bocheński thinks that the efforts of the Circle aiming at changing the Catholic thinkers' attitude towards modern formal logic were completely unsuccessful (cf. Bocheński 1989, p. 14). One of the reasons was the tragic death of Salamucha-the soul of the Circle-during World War II. However, the reasons were more complex. Bocheński writes:

The failure of the programme proposed by the Cracow Circle is not due to some peculiar Polish circumstances. It seems to be the result of the widespread resistance on the part of otherwise rationally thinking philosophers and theologians to recognize the significance of mathematical logic and analytic philosophy in any intellectual endeavour.

The case of the Cracow Circle is particularly sad. For Poland is one of among not so many countries that has had a flourishing school of logic and an efficient team of catholic scholars, who claimed to be rational. One would have expected that in such a country a new catholic philosophy and, in the first place, a new catholic theology should arise. Alas, this has not been the case (1989, pp. 15-16). 
Nonetheless, despite Bocheński's opinions the efforts of the Cracow Circle were continued-but not as extensively as one may expect. Besides the aforementioned works of Bendiek and Clark it is worth recalling the analyses of the five ways of Thomas Aquinas with the help of the instruments of modern logic undertaken by F. Rivetti Barbò, E. Nieznański or K. Policki. ${ }^{6}$ These authors used the strong tools of logic like the Kuratowski-Zorn lemma (Policki) or the theory of lattices (Nieznański).

Before proceeding to analysing the philosophical views of the Cracow Circle on logic and mathematics, we should mention their main achievements as far as the implementation of the tools of mathematical logic to solve philosophical and theological problems is concerned. These achievements include:

(1) logical analysis of the proof 'ex motu' for the existence of God, presented by St Thomas Aquinas in his Summa contra gentiles, undertaken by Salamucha (1934),

(2) formalisation and logical analysis of the proof for the immortality of the soul given by St Thomas Aquinas, formulated by Bocheński (1938),

(3) analysis of the scholastic concept of analogy-these investigations were initiated by Drewnowski (1934) and Salamucha (1937a), then developed by Bocheński (1948), ${ }^{7}$

(4) a certain number of works concerning the history of logic, particularly the history of Medieval logic - these investigations were characterised by looking at the old logic through the prism of modern logic ${ }^{8}$ - the works of Salamucha (1935, 1937b) or Bocheński's monograph (1956a), which was to some extent the culmination of this research trend,

(5) numerous works popularising Christian thought and the new style of its cultivation.

Our reflection on the philosophical views on logic and mathematics formulated by the scholars under consideration should begin with the analysis of Salamucha's views. Using the methods of logic to analyse the arguments of St Thomas Aquinas, Salamucha utilized the classical two-valued propositional calculus as well as the concepts of membership, relation and set. He referred to Principia Mathematica by Whitehead and Russell; he also used the symbols of their work. So he neither made use of semantic concepts nor the concept of truth, nor referred to the fundamental work of Tarski (1933). The aforementioned instruments were sufficient for him.

Formulating his conception of logic he cut himself off from nominalism, preserving neutrality towards the philosophical problems related to his idea. In footnote 4 to his work of 1934 , he wrote:

Although this way I am adopting much from mathematical logicians, it does not mean at all that I sympathize with their nominalistic point of view in logic and materialistic or positivistic tendencies in philosophy. I think that the same way as within traditional logic grounds different philosophical systems could

\footnotetext{
${ }^{6}$ The analysis of these attempts can be found in Nieznański's work (1987).

${ }^{7}$ For studies on analogy in the Cracow Circle see Wolak (2005).

8 This method was also used by Łukasiewicz—cf. Łukasiewicz (1951).
} 
occur equally in agreement or disagreement, it happens similarly within mathematical logic grounds, only in the second case more responsibility is required (2003). ${ }^{9}$

On the one hand, he understood logic —according to Koj (1995)—as an objective science the theses of which were formulated in an objective language and not in the metalanguage. On the other hand, he treated logic as a formal science and as such, it could not be placed on any floor of abstraction. Following Aristotle and Thomas, he saw logic as the science on operating concepts concerning reality and not as a science on reality alone. Therefore, logic is the science de entibus secundae intentionis. However, this clearly opposes the objective concept of logic. Salamucha was aware of this difficulty but did not develop this issue.

These problems appeared because of the question concerning the applicability of mathematical logic to metaphysical issues. According to the scholastic tradition mathematical logic is placed on the second level of abstraction whereas philosophy and in particular, metaphysics, on the third level. Salamucha did not reject this Medieval classification but sought a solution in the observation that Medieval mathematics and logic differed from modern mathematics and logic. In his paper ' $O$ możliwości ścisłego formalizowania dziedziny pojęć analogicznych' [On Possibilities of a Strict Formalization of the Domain of Analogical Notions] (1937a), he wrote that Medieval mathematics analysed the quantitative characteristics of objects whereas modern mathematics broke with this approach and 'for the majority of modern mathematicians mathematics is simply a deductive theory, in which from some axioms and definitions derivative theorems are derived with the help of logical theses, mathematics can contain no empirical elements ${ }^{10}$ (2003, p. 79). Thanks to that mathematics becomes similar to logic and along with the latter can-as noticed above-be treated as the science dealing with objects of second intention (cf. 1937a, p. 128). Salamucha adds:

In this way, mathematics has got closer to logic to such an extent that the boundaries between what has till recently been two branches of sciences, today slowly disappear and mathematics becomes simply a part of logic, only higher and deductively later than those parts of the same science which are commonly regarded as logic (2003, p. 79). ${ }^{11}$

\footnotetext{
9 'Chociaż w ten sposób zapożyczam wiele od logików matematycznych, nie znaczy to wcale, że solidaryzuję się $\mathrm{z}$ ich nominalistycznym nastawieniem w logice $\mathrm{i}$ z materialistycznymi czy pozytywistycznymi tendencjami w filozofii. Myślę, że tak samo jak na gruncie logiki tradycyjnej mogły występować równie zgodnie, czy równie niezgodnie, różne systemy filozoficzne, podobnie sprawa się przedstawia na gruncie logiki matematycznej, tyle, że tu obowiązuje większa odpowiedzialność' (1934).

10 'dla większości współczesnych matematyków matematyka jest po prostu teorią dedukcyjną, w której z pewnych aksjomatów i definicji wyprowadza się przy pomocy tez logicznych pewne twierdzenia pochodne - żadnych elementów doświadczalnych matematyka zawierać nie może’ (1937a, p. 132).

11 'W ten sposób matematyka zbliżyła się do logiki do tego stopnia, że granice między tymi dwiema do niedawna gałęziami nauk dziś powoli się zacierają i matematyka staje się po prostu częścią logiki, wyższą tylko i dedukcyjnie późniejszą od tych części tej samej nauki, które powszechnie za logikę są uważane' (1937a, p. 132).
} 
He summarises his considerations:

Thus, it appears that the fears that the application of logistic to metaphysics constitutes a violation of the differences between the traditional degrees of abstraction, are a result of some misunderstandings. Too great an emphasis has been laid upon the origin of logistic and modern mathematics has been confused with medieval mathematics $\left(2003\right.$, p. 83). ${ }^{12}$

In Salamucha's opinion, logic is a theory of deductive argumentation. Unfortunately, he did not develop this idea. Therefore, it is not clear-as Koj writes (1995, p. 20) — 'whether logic should be treated as a theory of consequences or whether only as metasystemic theses saying which objective theses should be accepted. ${ }^{13}$ However, logic enables us to control reasoning. Reasoning as a mental activity is not intersubjectively verifiable, but through ordering expressions to particular elements of reasoning and through the analysis of the operations conducted on these expressions we can check the conformity of inference with logical rules. Salamucha spoke here about methodological nominalism. It should be noted that it is something different than, for example, Chwistek's nominalism, ${ }^{14}$ which treats reasoning just as an operation on expressions (devoid of meaning). In Rev. Salamucha's opinion logic does not exclude meanings but only temporarilyexactly for methodological reasons-abstracts from them while analysing the arguments. Yet, Salamucha stressed that such a conception of logic did not force nominalism in philosophical theories in which it is utilised.

One of the consequences of such a conception of logic is the thesis that logic is not creative but only consists in checking the conducted activities (for instance, reasonings); it allows checking and ordering deduction. At the same time, it is to some extent a universal science, i.e. its theses can be used in all disciplines. Salamucha wrote that 'the normative consequences of logic embrace all fields of science and even ordinary life if we want it to be at least a little logical' (1936, p. 620). ${ }^{15}$

Salamucha did not claim that the formal logic of his times was a sufficient tool allowing the analysis and precise reconstruction of the whole of scholastic philosophy. When asked whether logic was such a sufficient tool he said that he did not know that. Referring to Principia Mathematica, he claimed that it was sufficient to construct the whole of mathematics. However, he did not exclude the fact that in

\footnotetext{
12 'Okazuje się, że obawy, jakoby zastosowanie logistyki do metafizyki było pogwałceniem różnic między tradycyjnymi stopniami abstrakcji, są wynikiem pewnych nieporozumień; kładzie się zbyt wielki nacisk na pochodzenie logistyki i miesza się matematykę współczesną z matematyką średniowieczną' (1937a, p. 137).

13 'czy logikę [należy] traktować jako teorię konsekwencji, czy tylko jako metasystemowe tezy mówiące, jakie tezy przedmiotowe należy przyjać.'

14 On Chwistek's philosophy of logic and mathematics and in particular on his nominalizm see Murawski (2011a, b).

15 'normatywne konsekwencje logiki obejmują wszystkie dziedziny naukowe i nawet życie potoczne, jeżeli chcemy, żeby ono było choć trochę logiczne.'
} 
the future it would be necessary to enlarge logic so that we might use it to make adequate analyses of philosophical problems. ${ }^{16}$ Salamucha realised that his investigations and those conducted by the Cracow Circle were something new and belonged to the domain which had not been developed before. Concluding his paper 'O możliwości ścisłego formalizowania ...' he wrote:

The arguments of this paper resemble forcing one's way through a jungle, where man rarely enters; logisticians who are not interested in scholasticism do not enter there-scholastics who are not interested in logistic do not enter there (2003, p. 95). ${ }^{17}$

In Salamucha's opinion, one of the problems that should be solved and developed was the issues related to analogy. The adversaries of the Cracow Circle raised the reservation-because of the use of formal logic in metaphysics - that the latter used analogous concepts whereas logic aimed at providing precise concepts and making them unambiguous. Rev. Salamucha did not have a solution for that but he saw that the concept of analogy, which scholastics used, was vague and pointed to some ideas of Drewnowski included in his work 'Zarys programu filozoficznego' [Outline of a Philosophical Programme] (1934). Consequently, he formulated the following interesting opinion:

It seems, however, that in metaphysics an adequately interpreted metalogic is going to be more useful than modern formal logic itself $\left(2003\right.$, p. 94). ${ }^{18}$

As for the philosophical problems related to mathematics, we should also consider Salamucha's opinion that the appearance of non-Euclidean geometries and the creation of relativity theory allowed us to break down-as he wrote-the tyranny of time and space. He argued that both concepts were non-empirical and because of that we could not empirically confirm the influence of time and space on physical phenomena. Thanks to these new theories, the concept of space became 'empirically reversed' and 'space is only a conceptual construction and this construction can be undoubtedly and consistently developed in many different ways' (1946). ${ }^{19}$ It is not clear what Salamucha meant by that. Since if geometry is to be understood as a formal science, experience does not play any role in recognising its theorems as true or rejecting them as false. Both types of geometry-Euclidean and non-Euclidean-have the same epistemological status in this conception. However, if this or that geometry is used to construct physical models, experience

\footnotetext{
16 This need was also presented clearly by Bocheński when he tried to formulate certain aspects of the problem of universals using the terms of modern logic — cf. Bochenski (1956b). He claimed that logicalmathematical investigations concerning certain questions connected with the problem of universals might require stronger logical and semantic tools than those that were available at that time.

17 'Wywody tego artykułu są trochę takie, jak przedzieranie się przez gąszcze, gdzie rzadko wdziera się człowiek; nie wchodzą tam logistycy, których scholastyka nie interesuje, - nie wchodzą tam scholastycy, którzy nie zajmują się logistyką' (1937a, p. 152).

18 'Zdaje się jednak, że w metafizyce bardziej przydatna okaże się metalogika, odpowiednio tylko interpretowana, aniżeli sama współczesna logika formalna' (1937a, p. 151).

19 'doświadczalnie wywracane'; 'przestrzeń jest tylko konstrukcją pojęciową i można tę konstrukcję konsekwentnie i bezsprzecznie na różne sposoby rozbudowywać.’
} 
will play a fundamental role here and will determine the adequacy of the description provided by the given model.

Finally, our reflection on Salamucha's views should include his praise of Roman Ingarden's criticism of the philosophy of the Vienna Circle and his answer to the question of using formal logic in phenomenology. Salamucha agrees with Ingarden to some extent, writing:

If one claims, together with Prof. Ingarden, that all and only those issues belong to philosophy which concern either (a) "pure possibilities or necessary relations between possibilities" or (b) "the real existence of all possible domains of being" and "the real essence of both entire domains of being and their particular elements", where the main stress is laid upon the subject (a), then one will have to accept - at most with some small reservations - that the methods of particular sciences, and hence also the deductive method, will have no application to philosophy $(2003$, p. 84$) .^{20}$

However, this would lead-according to Salamucha-to a radical reduction of philosophical problems. Yet, if one wants to cultivate Thomistic philosophy and theology, the utilisation of logistic tools is fully justified.

Let us proceed to the views concerning logic of another member of the Cracow Circle Jan F. Drewnowski. He formulated a more refined philosophical conception than the other members did-cf. his 'Zarys programu filozoficznego' [Outline of a Philosophical Programme] (1934), which became a kind of manifesto of the Cracow Circle although the other members of the Circle referred to it rather loosely. Drewnowski-as opposed to Salamucha or Bocheński-did not follow Thomism but chose his own way. In addition, he was an expert in natural sciences. His philosophical programme was based on the interdependence of various fields of science, especially logic, natural sciences, mathematics and theology.

Drewnowski's aim was to propose a new philosophical language that could be used to express the views of many different philosophers, in particular the theses of modern scientific philosophical theories and the theses of classical philosophy, including Thomism.

One of the important components of Drewnowski's programme was his theory of signs. In his opinion, signs play a substitutive role, allowing us to get to know the real world by going beyond direct sensations and by creating systems. ${ }^{21}$ However, we should expect to face here certain threats, which Drewnowski specified in 'Zarys': ${ }^{22}$

\footnotetext{
20 'Jeżeli się przyjmie, razem z prof. Ingardenem, że do filozofii należą te wszystkie zagadnienia i tylko te, które dotyczą: (a) czystych możliwości lub koniecznych związków między możliwościami lub (b) faktycznego istnienia wszelkich możliwych dziedzin bytu i faktycznej istoty zarówno całych dziedzin bytowych jak i ich poszczególnych elementów, przy tym główny nacisk położy się na tematach a, to - co najwyżej z pewnymi małymi zastrzeżeniami - trzeba będzie uznać, że metody nauk szczegółowych, a więc i metoda dedukcyjna, nie znajdą w filozofii zastosowania' (1937a, p. 139).

21 One can say that Drewnowski has ancitipated in a way some of the ideas of Jacques Derrida.

22 All of the quotations come from 'Zarys programu filozoficznego,' included in Drewnowski's collection of selected works Filozofia i precyzja [Philosophy and Precision] (1996).
} 
Falling into a habit of constant intercourse with signs instead of reality itself, meaning - so to say - an intentional attitude towards reality, causes in the long run that the sense of this intentionality is blurred (1996, p. 58). ${ }^{23}$

On the one hand, identifying signs with reality can reduce reality to what the signs define and on the other hand, can recognise what the signs give as some new domain of reality. ${ }^{24}$

At first, signs substitute the reality under consideration and then help in theoretical considerations, which leads to the so-called pile-up of signs, i.e. groups of signs are replaced by other signs. Not paying attention to this problem may lead to a misunderstanding. Additionally, one should distinguish between signs and the instructions describing how to use these signs.

Drewnowski distinguished three kinds of theories: scientific, mathematical and theological. All of them are systems of signs. Drewnowski formulated rules of using signs for each kind of these theories and reflected on the relationships between the theories.

Having presented the general remarks we can proceed to discussing Drewnowski's views on mathematics and logic as well as the applicability of logic to other sciences. Let us begin with his remarks on axioms and definitions. He claims that:

Axioms are either expressions of certain presumptions of the so-called laws that are binding in a given domain or they are only expressions of certain agreements accepted within a given notation. In both cases they do not express anything absolute: in the first case - it is more correct to formulate them as suitable conditions and put them in an abbreviated way in the antecedents of the theorems of a theory ${ }^{25}$; in the other - they belong to regulatory instructions, and it is more correct to formulate them as appropriate directives (1996, p. 67). ${ }^{26}$

Drewnowski views definitions in a similar way.

In Drewnowski's approach mathematical theories are 'the same sign mechanisms as other theories of natural sciences' $\left(1996\right.$, p. 71). ${ }^{27} \mathrm{He}$ describes them more precisely in 'Zarys':

Their characteristics are that they are tools to analyse scientific theories themselves and all other systems of signs that look like scientific theories.

\footnotetext{
23 'Przyzwyczajenie do ciągłego obcowania ze znakami zamiast z samą rzeczywistością, czyli taki - że tak powiem - intencjonalny stosunek do rzeczywistości, sprawia na dalszą metę zatarcie się poczucia tej intencjonalności.'

24 Twardowski also warned against this kind of errors (cf. his 'Symbolomania i pragmatofobia' [Symbolomania and pragmatophobia], 1927). In turn, Łukasiewicz recommended a constant contact with reality while using developed philosophical systems.

25 We are dealing here with the theorem of deduction-remark is mine.

26 'Aksjomaty są wyrazem bądź pewnych przypuszczeń co do obowiązujących w danej dziedzinie tzw. praw, bądź też tylko są wyrazem pewnych umów przyjętych w obrębie danego znakowania. I w jednym, i w drugim wypadku nie wyrażają niczego bezwzględnego: w pierwszym - poprawniej jest sformułować je jako odpowiednie warunki i w skrócony sposób wymieniać je w poprzednikach twierdzeń teorii; w drugim wypadku - należą do instrukcji wykonawczej, i poprawniej jest sformułować je jako odpowiednie dyrektywy.'

27 'są takimi samymi mechanizmami znakowymi, jak inne teorie przyrodnicze.'
} 
They deal only with the properties of the construction of the systems of signs occurring in theories, namely the dependence of various structural types of complex signs on the ways of using them, in accordance with the regulatory instructions of a given theory. [...] Therefore, the only type of operations on mathematical theories is the operations that mark the deduction of propositions and similar inter-propositional relations (1996, pp. 71-72). ${ }^{28}$

What is the relation of the commonly understood mathematics towards the mathematical theories thus characterised? Drewnowski claims that some parts of mathematics are scientific theories, in particular the arithmetic of natural numbers based on the primary concepts of quantity and sign. Natural theories include, in Drewnowski's opinion, 'all geometries if they concern some extensive properties and do not move to generalisations, dealing with any relations of which a special case is a given relation occurring in some empirical extension' $\left(1996\right.$, p. 73). ${ }^{29}$ The remaining part of 'contemporary mathematics can probably be comprised in the socalled theory of relations, i.e. it will depend on what I call here mathematical theories' (1996, p. 73). ${ }^{30}$ In addition, for a mathematical theory it does not matter what the signs signify, and consequently, 'the propositions of mathematics are devoid of any definite meaning' (ibid.). ${ }^{31}$ The identification of mathematics with mathematical theories leads to the thesis that 'objects with which mathematics deals are arbitrary human creations' (ibid.). ${ }^{32}$ The problem of existence of mathematical objects can be reduced to the existence of signs which a given theory uses-as opposed to the scientific theories 'where the indispensible condition of correctness, the verifiability of arguments, will always be to indicate the way of making available to the analysis what the theory is about' $(1996$, p. 74$) .^{33}$

According to Drewnowski, such mathematical theories include all the generalisations of philosophy and the whole part of metaphysics dealing with general laws. However, he regards the incompetent mathematisation of various domains as wrong. At this point, it results from the schematisation of mathematical domains 'which do not know the dependencies that modern mathematics investigates' or attempts 'to transfer only mathematical symbols to various considerations, e.g. historical-philosophical ones, by those who do not know mathematics' (1996,

\footnotetext{
28 'Charakterystyczną cechą ich jest to, że sạ narzędziami do badania samych teorii przyrodniczych i wszelkich innych układów znaków, wyglądających jak teorie przyrodnicze. Zajmują się one wyłącznie właściwościami budowy układów znaków występujących w teoriach, mianowicie tym, jak uzależnione są różne typy strukturalne znaków złożonych od sposobów posługiwania się nimi, zgodnie z instrukcjami wykonawczymi danej teorii. [...] Jedynym więc typem operacji na gruncie teorii matematycznych są te, które znaczą wywiedlność zdań i pokrewne zależności międzyzdaniowe.'

29 'wszelkie geometrie o tyle, o ile zajmują się jakimiś własnościami rozciągłymi, a nie przechodzą do uogólnień zajmujących się dowolnymi stosunkami, których szczególnym przypadkiem bywa dany stosunek występujący w jakiejś rozciągłości doświadczalnej.'

30 'współczesnej matematyki da się prawdopodobnie objąć tzw. teorią stosunków, czyli należeć będzie do tego, co nazywam tu teoriami matematycznymi.'

31 'zdania matematyki są pozbawione określonego znaczenia.'

32 'twory, którymi zajmuje się matematyka, są dowolnymi wytworami ludzkimi.'

33 'gdzie zawsze niezbędnym warunkiem poprawności, sprawdzalności wywodów będzie wskazanie sposobu udostępniania badaniu tego, o czym mowa w teorii.'
} 
p. 75). ${ }^{34}$ The starting point of the correct mathematisation of a theory must be suitable scientific theories based on empirical data-Drewnowski includes here 'colour or tactile qualities serving as the starting point to construct the notions of physics, such as the sensations of pain, fear, adoration, the sense of ownership, of rightness, etc., which can serve as the starting points of many different scientific theories' (1996, p. 76). ${ }^{35}$ Such theories can then be mathematised. Drewnowski describes this process as follows:

It will consist in that: as the given scientific theory is being developed, its dependencies are getting more and more complicated; it will be stated that such dependencies are special relations, worked on in the mathematical theories. Then the whole part of a proper mathematical theory can be used in the given scientific theory by substituting the signs of the dependences occurring in the scientific theory, which are special relations, analysed in the mathematical theory, in the correct theorems of the mathematical theory. And reversely - various new dependencies in the given scientific theory can incline us to generalise them and thus provide new problems to the mathematical theories $\left(1996\right.$, p. 76). ${ }^{36}$

Drewnowski regards the features of the mathematical theories as the advantages and benefits of this mathematisation, writing:

The value of this mathematisation of knowledge will occur even more clearly when on the one hand, it is considered that the mathematical theories owe their efficiency to their higher degree of generality: analysing the dependencies, without considering their meanings, allows making many attempts and modifications, which would not be easy within the framework of some scientific theory in which the meanings of signs, many a time loaded with tradition, habits, hinder the movements $(1996$, p. 76$) .{ }^{37}$

\footnotetext{
34 'którym obce są te zależności, jakimi zajmuje się współczesna matematyka'; 'przenoszenia samych tylko symboli matematycznych do różnych rozważań, np. historiozoficznych, przez osoby nie znające matematyki.'

35 'jakości barwne lub dotykowe, służące za punkt wyjścia do budowy pojęć fizyki, jak doznania bólu, strachu, uwielbienia, poczucia własności, słuszności itp., mogące służyć za punkty wyjścia szeregu innych teorii przyrodniczych.'

36 'Będzie to polegać na tym, że w miarę rozwijania się danej teorii przyrodniczej, komplikacji występujących w niej zależności, stwierdzać się będzie, iż pewne takie zależności są szczególnymi przypadkami stosunków, opracowywanych w teoriach matematycznych. Wówczas cała ta część odpowiedniej teorii matematycznej może być zastosowana do danej teorii przyrodniczej drogą podstawienia w odpowiednich twierdzeniach teorii matematycznej znaków tych zależności teorii przyrodniczej, które sạ szczególnymi przypadkami stosunków badanych w teorii matematycznej. Odwrotnie też - różne nowe zależności w danej teorii przyrodniczej mogą skłaniać do uogólniania ich i dostarczać w ten sposób nowych zagadnień teoriom matematycznym.'

37 'Wartość tak pojętego matematyzowania wiedzy wystąpi jeszcze wyraźniej, gdy się zważy, że z jednej strony teorie matematyczne zawdzięczają swoją sprawność większej swej ogólności: zajmowanie się zależnościami, bez oglądania się na ich znaczenie, pozwala na dokonywanie wielu prób i przeróbek, które nie byłyby łatwe w obrębie jakiejś teorii przyrodniczej, gdzie znaczenia znaków, obarczone nieraz tradycją, nawykami, utrudniają swobodę ruchów.'
} 
On the other hand, considering the possible applications of the mathematical theories allows us to choose from 'a surplus of possible combinations' those which are more desired.

Drewnowski also considered the problem of applying symbolic logic, especially to philosophy. He wrote a special paper on this question in 1965, referring to D. Hilbert and W. Ackermann's Grundzüge der theoretischen Logik (1928), which-as he notices-characterises the method of this application of logic. He describes the method in the following words: ${ }^{38}$

The method establishes constant symbols, expressing the specific notions of a given domain, and describes the types of objects marked by the arguments of these new functional symbols. With the help of these new symbols and the symbols of functional calculus, ${ }^{39}$ the symbolic formulations of the premises from the given domain are provided. The formulated premises are added to the axioms of functional calculus as new axioms. From this, using the rules of inference of functional calculus, we receive theorems, being the symbolic formulations of what we want to prove in the given domain (Drewnowski 1996, p. 199). ${ }^{40}$

At the same time, he notices that such an application of the predicate calculus is not an interpretation of the symbols of the language of this calculus because 'all the time these symbols are used in the same general logical meaning as in the classical logical calculus' (1996, pp. 199-200). ${ }^{41}$ The symbolic formulation of the assumed properties of the analysed objects in the form of axioms can feature certain general dependencies in a given domain, and the axioms 'do not have to use up semantically the content of the notions and all the dependencies of this domain' (1996, p. 200). ${ }^{42}$ Such an application of the logical tools to define precisely the given domain of knowledge does not violate the richness of its content. The application of these tools is possible to the extent that 'the rational cognition of the given domain of reality' (1996, p. 200) ${ }^{43}$ is possible. Moreover, Drewnowski clearly opposes the view that symbolic logic cannot be used outside of mathematics, in particular in philosophy. He criticises the arguments formulated by the followers of this standpoint, especially the opinions presented by the adherents of the so-called existential

\footnotetext{
38 Like in the case of 'Zarys programu filozoficznego' the page numbering is from Drewnowski's selected works Filozofia i precyzja (1996).

39 The old name of the predicate calculus-remark is mine.

40 'Metoda ta polega na tym, że ustala się nowe symbole stałe, wyrażające swoiste pojęcia danej dziedziny, i opisuje się rodzaje przedmiotów oznaczonych przez argumenty tych nowych symboli funkcyjnych. Za pomocą tych nowych symboli oraz symboli rachunku funkcyjnego podaje się symboliczne sformułowania przesłanek $\mathrm{z}$ danej dziedziny. Tak sformułowane przesłanki dołącza się do aksjomatów rachunku funkcyjnego jako nowe aksjomaty. Stąd zaś, stosując reguły wnioskowania rachunku funkcyjnego, otrzymuje się twierdzenia, będące symbolicznymi sformułowaniami tego, czego się chce dowieść w danej dziedzinie.'

41 'symbole te cały czas są użyte w tym samym ogólnologicznym znaczeniu, jakie mają w klasycznym rachunku logicznym.'

42 'nie muszą wyczerpywać znaczeniowo treści pojęć i wszelkich zależności tej dziedziny.'

43 'rozumne poznanie danej dziedziny rzeczywistości.'
} 
Thomism who claim that 'metaphysics cultivated in this spirit has separate methods of reasoning, and symbolic logic cannot be used here' (1996, pp. 200-201). ${ }^{44}$ This problem was already considered by Ajdukiewicz in 'O stosowalności czystej logiki do zagadnień filozoficznych' [On Applicability of Pure Logic to Philosophical Questions] (1934). He asked whether modern logic, which was extensional, could be used to solve philosophical problems formulated in the intentional colloquial language. In the aforementioned paper (1965), Drewnowski analysed three meanings of extensionality and stated that equivalential extensionality of classical logical calculus was not an obstacle to using this calculus in philosophy. He also explained how to use logic to solve philosophical and theological problems in the works of the Cracow Circle:

All of our attempts neither interpreted logical symbols nor translated metaphysics into the language of symbolic logic. The method of applying symbolic logic, which we have utilised, was just [...] the application of the very classical logical calculus, to which new constant symbols are added (1996, pp. 203-204). ${ }^{45}$

Let us proceed to the last member of the Cracow Circle-Fr Józef (Innocenty) Maria Bocheński. At this point, a certain problem is the evolution of his philosophical views. Since Bocheński was a follower of Kant, and then of neoThomism. He attempted to modernise the latter by using the tools of mathematical logic. Finally, he departed from the problem of being and moved towards analytic philosophy. Since our paper concerns the pre-war period we are not going to analyse his post-war views but focus on his activities in the Cracow Circle (however, we will sometimes refer to his later activities).

According to the Cracow Circle, if Thomism wants to be a rational philosophywhich it has been since the very beginning-it must know and use modern formal logic. This logic gives precision, which Bocheński understood in the following way:

Our way of speaking is called 'precise', when it observes the following rules: As far as words are concerned, they must be unequivocal signs of simple things, features, experiences, etc.; they are to be clearly defined in relation to these simple signs, in accordance with precisely stated rules. Furthermore, these words should be always used in such a way that each one of them constitutes a part of a proposition, i.e. expression that is true or false. Where propositions are concerned, they cannot be accepted until we know exactly what they mean and why we assent to them. Sometimes we accept them as evident, sometimes on the basis of faith or proof - in the latter case it should

\footnotetext{
44 'metafizyka uprawiana w tym duchu ma odrębne metody rozumowania i logika symboliczna nie daje się tu stosować.'

45 'Otóż wszystkie te nasze próby nie były ani interpretowaniem symboli logicznych, ani przekładaniem metafizyki na język logiki symbolicznej. Metoda stosowania logiki symbolicznej, jaką się posługiwaliśmy, była właśnie [...] stosowaniem samego tylko klasycznego rachunku logicznego, do którego dodaje się nowe symbole stałe.'
} 
be conducted on the basis of clearly formulated and efficient logical directives (1937, pp. 28-29). ${ }^{46}$

Additionally, precise speaking and thinking should be characterised by the use of formal logic and exclusion of such irrational factors as will, emotion, imagination. Bocheński was convinced that the best available logic is mathematical logic (formal logic, logistic)_cf. for example (1936)_but later he thought that certain philosophical problems required richer logical tools.

After the war, he rejected Thomism and followed analytic philosophy, being faithful to the discussed metaphilosophical principle and stressing the question of the method. Doubting whether one exact philosophical system, embracing all philosophical issues, could be built he analysed unconnected problems separately, always using exact logical methods.

Refuting the accusations that were made during the discussion at the aforementioned meeting of the Cracow Circle in Kraków in August 1936, Fr Bocheński paid attention to the necessity of distinguishing between formal logic and philosophy as well as to the fact that in antiquity there had been logical systems different from Aristotle's logic. Similarly, in logistic it is the classical two-valued logic that plays a fundamental role. At the same time, formal logic does not focus so much on the truth of conclusions deduced by applying logical tools-it is the task of other sciences - but on the truth of its theses. He also stressed the possibility of using many-valued logics in theology. These logics could be treated as the logics of probability and utilised to evaluate the degrees of falsity-this may allow us to realise the idea of St Thomas Aquinas. Moreover, Bocheński claimed that the process of constructing logical systems did not assume any philosophical presumptions-logic is and should be neutral. The fact that mathematical logic grew out of mathematics, and like mathematics it uses symbolic notation, does not mean that formal logic can be used only in mathematics. It can and should be used wherever deduction is used-the deduction should be always exact and accurate.

When Bocheński cultivated philosophy in the spirit of analytic philosophy, he used the broadly understood logic, embracing formal logic as well as semiotics, which was based on it, and the general methodology of sciences. In his opinion, this conception of logic is an ideal pattern of rationality; it provides notional tools to analyse complex argumentations and to analyse notions. It constitutes the organon of philosophy and being a kind of ontology it constitutes a branch of philosophy. ${ }^{47}$

\footnotetext{
46 'Ścisłym nazywamy sposób mówienia, w którym obowiązują następujące zasady: Jeśli chodzi o użyte słowa, mają one być bądź niedwuznacznymi znakami prostych rzeczy, cech, doznań itp., bądź też być na gruncie poprawnie sformułowanych dyrektyw za pomocą takich właśnie znaków jasno zdefiniowane. Słowa te mają być dalej użyte zawsze tak, by każde z nich stanowiło część zdania, to jest wyrażenia, które jest prawdziwe albo fałszywe. Jeśli chodzi o zdania mogą one być uznane dopiero wtedy, gdyśmy sobie w pełni zdali sprawę, co znaczą i dlaczego je uznajemy. Racją tego uznania będzie niekiedy oczywistość, niekiedy wiara, niekiedy dowód - w ostatnim przypadku ma on być przeprowadzony na gruncie jasno sformułowanych i sprawnych dyrektyw logicznych.'

47 Bocheński wrote in (1980): “In fact [modern logic] deals with 'ultimate foundations' and it consists of axiomatic study of most abstract properties of any objects. Just therefore Heinrich Schulz claimedrightly as it seems - that modern logic is an ontology being a fundamental part of philosophy."
} 
According to Bocheński modern logic is an autonomous science-but not only this kind of logic. In fact, in every epoch a highly developed logic had the right to be characterised as autonomous (cf. his paper of 1980). Asked whether modern logic is a mathematical discipline or whether it should be included in philosophy he answers (1980) that it depends on the definitions of mathematics and philosophy. If mathematics is defined through its method, logic, using the same method and having the same characteristics (symbolic, formalistic, deductive, objective, etc.) as the mathematical sciences, should be regarded as a mathematical discipline. As a matter of fact, the boundaries between modern logic and mathematics are blurred. However, logic has two features that distinguish it from mathematics. The first one is the maximal generality of its fundamental branches such as propositional calculus, predicate calculus or the logic of relations and the second is its higher degree of exactness (cf. Bocheński 1980, Section VI). On the other hand, assuming that philosophy analyses the foundations and most general properties of objects, modern logic, as any logic, becomes part of philosophy (ibid., Section VII). This thesis is also supported-in Bocheński's opinion-by the fact that modern logic has given solutions to many traditional philosophical problems. He mentions Russell's conception of logical paradoxes and his theory of systematic ambiguity. This isaccording to Bocheński-a solution of the eternal problem of the 'univocity of being'. Further he mentions Tarski's definition of truth as well as Gödel's first incompleteness theorem. He claims that the latter has shown among other things that there are no philosophical systems that could embrace the whole of reality (like Hegel's system). Thus logic, as a tool of philosophy, is also its part. This is also possible when logic is a part of mathematics, which results from-according to Bocheński-the fact that it is the most general and fundamental part of mathematics. It seems - he adds - that "the same truths are obligatory in the fundamental parts of all sciences” (Bocheński 1980, Section VII).

Acknowledgments The financial support of the National Center for Science [Narodowe Centrum Nauki] (Grant No N N101 136940) is acknowledged.

Open Access This article is distributed under the terms of the Creative Commons Attribution License which permits any use, distribution, and reproduction in any medium, provided the original author(s) and the source are credited.

\section{References}

Ajdukiewicz K (1934) O stosowalności czystej logiki do zagadnień filozoficznych. Przegląd Filozoficzny $37: 323-327$

Bendiek J (1949) Scholastische und mathematische Logik. Franziskanische Studien 31:13-48

Bendiek J (1956) Zur logischen Struktur der Gottesbeweise. Franziskanische Studien 38:1-38, 296-321

Bocheński JM (1936) W sprawie logistyki. Verbum 3:445-454

Bocheński JM (1937) Tradycja myśli katolickiej a ścisłość. In: Myśl katolicka wobec logiki współczesnej, Studia Gnesnensia 15:27-34

Bocheński JM (1938) Analisi logica di un testo di S. Tomasso d'Aquino (I,75,6). In: Nove lezioni di logica simbolica, Angelium, Roma, pp 147-155 
Bocheński JM (1948) On analogy, The Thomist 11:474-497. Reprinted in: Menne A (ed), Logicophilosophical studies, D. Reidel, Dordrecht 1962, pp 96-117

Bocheński JM (1956a) Formale Logik. Verlag Karl Alber, Freiburg/München

Bocheński JM (1956b) The problem of universals. In: Bocheński JM, Church A, Goodman N (eds) The problem of universals. University of Notre Dame Press, Notre Dame, pp 33-54

Bocheński JM (1980) The general sense and Charakter of modern logic. In: Agazzi E (ed) Modern logica survey. D. Reidel Publishing Company, Dordrecht, pp 3-14

Bocheński JM (1989) The Cracow Circle. In: Szaniawski K (ed) The Vienna circle and the Lvov-Warsaw School. Kluwer Academic Publishers, Dordrecht, pp 9-18

Clark JT (1952) Conventional logic and modern logic. A prelude to transition. Woodstock College Press, Woodstock

Drewnowski JF (1934) Zarys program filozoficznego, Przegląd Filozoficzny 37:3-38, 150-181 and 262-292. Reprinted in: Drewnowski (1996), pp 55-147

Drewnowski JF (1965) Stosowanie logiki symbolicznej w filozofii. Studia Philosophiae Christianae 1:53-65

Drewnowski JF (1996) Filozofia i precyzja. Zarys programu filozoficznego $i$ inne pisma, Wydawnictwo Towarzystwa Naukowego Katolickiego Uniwersytetu Lubelskiego, Lublin

Hilbert D, Ackermann W (1928) Grundzüge der theoretischen Logik. Julius Springer, Berlin

Koj L (1995) Ks. Jana Salamuchy koncepcja logiki. In: Wolak Z (ed) Logika i metafizyka, Biblos, Tarnów-OBI, Kraków, pp 15-31

Łukasiewicz J (1927) O metodę w filozofii. Przegląd Filozoficzny 31:3-5

Łukasiewicz J (1951) Aristotle's Syllogistic from the Standpoint of Modern Formal Logic, Clarendon Press, Oxford. Second edition (including the chapter on syllogistic of modal sentences): Clarendon Press, Oxford 1957. Polish translation: Sylogistyka Arystotelesa z punktu widzenia wspótcze-snej logiki formalnej, Państwowe Wydawnictwo Naukowe, Warszawa, 1988

Murawski R (2011a) Filozofia matematyki i logiki w Polsce miedzywojennej, Monografie Fundacji na rzecz Nauki Polskiej, Wydawnictwo Naukowe Uniwersytetu Mikołaja Kopernika, Toruń

Murawski R (2011b) On Chwistek's philosophy of mathematics. In: Griffin N, Linsky B, Blackwell K (eds) Principia mathematica at 100, The Bertrand Russell Centre, Hamilton, Ontario, 2011, pp 121-130. Also in: Russell: The Journal of Bertrand Russell Studies 31:121-130 (2011)

Nieznański E (1987) Logical analysis of Thomism. The Polish programme that originated in 1930's, In: Srzednicki J (ed) Initiatives in logic. Martinus Nijhoff Publishers, Dordrecht/Boston/Lancaster, pp 128-155. Reprinted in: Salamucha (2003), pp 363-393

Salamucha J (1934) Dowód ex motu na istnienie Boga. Analiza logiczna argumentacji św. Tomasza z Akwinu, Collectanea Theologica 15:53-92. English translation: The proof ex motu for the existence of God. Logical analysis of St. Thomas' arguments, The New Scholasticism (1958), 32:327-372. New English translation: The proof ex motu for the existence of God. Logical analysis of St. Thomas Aquinas' arguments, in: Salamucha (2003), pp 97-135

Salamucha J (1935) Logika zdań u Wilhelma Ockhama, Przegląd Filozoficzny 38:208-239; German translation: Die Aussagenlogik bei Wilhelm Ockham. Franziskanische Studien (1950), 32:97-134. English translation: The propositional logic in William Ockham, in: Salamucha (2003), pp 139-167

Salamucha J (1936) Zza kulis filozofii chrześcijańskiej, Verbum 3:613-627. Reprinted in: Salamucha (1997), pp 181-186

Salamucha J (1937a) O możliwości ścisłego formalizowania dziedziny pojęć analogicznych. In: Myśl katolicka wobec logiki współczesnej, Studia Gnesnensia 15:122-153. English translation: On possibilities of a strict formalization of the domain of analogical notions. In: Salamucha (2003), pp 71-95

Salamucha J (1937b) Pojawienie się zagadnień antynomialnych na gruncie logiki średniowiecznej. Przegląd Filozoficzny 40:68-89, 320-343. English translation: The appearance of antinomial problems with medieval logic. In: Salamucha (2003), pp 169-210

Salamucha J (1946) Czas, przestrzeń i wieczność, Dziś i Jutro 2, nr 17(23):3-4. Reprinted in: Salamucha (1997), pp 83-88

Salamucha J (2003) Knowledge and faith. Edited by Świetorzecka K, Jadacki JJ, Rodopi, Amsterdam, New York

Tarski A (1933) Pojecie prawdy w jezykach nauk dedukcyjnych. Towarzystwo Naukowe Warszawskie, Wydział III Nauk Matematyczno-Fizycznych, Vol. 34, Warszawa (reprinted in: A. Tarski, Pisma logiczno-filozoficzne, vol. 1: Prawda. Wydawnictwo Naukowe PWN, Warszawa 1995, 131-172). English translation: The concept of truth in formalized languages. In: A. Tarski, Logic, semantics, 
metamathematics. Papers from 1923 to 1938. Clarendon Press, Oxford 1956, 152-278 and in: A. Tarski, Logic, Semantics, Metamathematics. Papers from 1923 to 1938, second edition edited and introduced by J. Corcoran. Hackett Publishing Co., Indianapolis, 1983, 152-278

Twardowski K (1927) Symbolomania i pragmatofobia. In: Rozprawy i ar-tykuty filozoficzne, Lwów, pp 394-406. Reprinted in: Wybrane pisma fi-lozoficzne. Państwowe Wydawnictwo Naukowe, Warszawa 1965, pp 354-363

Wolak Z (1993) Neotomizm a Szkoła Lwowsko-Warszawska. Ośrodek Badań Interdyscyplinarnych, Kraków

Wolak Z (1996) Zarys historii Koła Krakowskiego. In: Z. Wolak (red.), Logika i metafizyka, Biblos, Tarnów-OBI, Kraków, pp 79-84

Wolak Z (2005) Koncepcje analogii w Kole Krakowskim. Wydawnictwo Diecezji Tarnowskiej Biblos, Tarnów

Woleński J (1989) Logic and philosophy in the Lvov-Warsaw School. Kluwer Academic Publishers, Dordrecht

Woleński J (2003) Polish attempts to modernize Thomism by logic (Bocheński and Salamucha). Studies in East European Thought 55:299-313. Reprinted in: J. Woleński, Historico-Philosophical Essays, vol. 1, Copernicus Center Press, Kraków 2012, pp 51-66 